\title{
Studies on serum cholinesterase isoenzymes in laboratory animals: Serum cholinesterase isoenzyme patterns and cholinesterase activities animal species.
}

\author{
Fumiaki Akahori ${ }^{1)}$, Kazuko Sakaguchi' ${ }^{2)}$, Ryuko Kohzaki ${ }^{2}$, \\ Toshio Masaoka ${ }^{1)}$ and Shigeyuki Arai ${ }^{1)}$
}

\begin{abstract}
SUMMARY
We analyzed cholinesterase (ChE) isoenzyme patterns of various laboratory animal species using electrophoresis to explore possible species-related variations and also to determine if there is a relationship between the $\mathrm{ChE}$ activity and the $\mathrm{ChE}$ isoenzyme pattern.

The laboratory animals that we used were Standard Wistar and Spraque-Dawley rats, Djungarian hamsters, Hartley guinea pigs, Japanese white rabbits (JW-NIBS strain), Beagle dogs, Japanese monkeys, Yorkshire pigs, Thoroughbred horses and Japanese quail. The ChE isoenzyme patterns were determined using polyacrylamide gradient gel electrophoresis (PAG-EP). The activity of serum ChE was measured using Ellman's method. The ChE isoenzymes of Wistar and SpragueDawley rats consisted of six separate fractions and sex- and/or age-related differences in the number of fractions were not observed. However, a sex-related variation was observed in the proportions of individual $\mathrm{ChE}$ isoenzyme bands for both rat strains. Also a sex-related difference was demonstrated in the serum ChE activity. The number of fractions of the ChE isoenzyme exhibited a species-related variations in the other animals. Hamsters, guinea pigs, rabbits, dogs, monkeys, pigs, horses and quails had 4, 3, 4, 3-5, 3, 3, 4 and $3 \mathrm{ChE}$ isoenzyme bands, respectively. However, with the exception of the rats, the hamsters, guinea pigs, rabbits, dogs, monkeys, pigs, horses and quail did not show any sex-related difference in the proportions of their ChE isoenzyme bands or in the ChE activities.

Therefore, it appears that there is a relationship between the serum $\mathrm{ChE}$ activity and the proportion of $\mathrm{ChE}$ isoenzyme bands. These results suggest a possible species-related variation in the mode of polymerization of serum $\mathrm{ChE}$ subunits that constitute the $\mathrm{ChE}$ isoenzymes.
\end{abstract}

Key words: ChE isoenzyme, species-specificity.

実験動物における血清コリンエステラーゼアイソザイムの研究：各種動物における血清コリンエステラーゼ アイソザイムと血清コリンエステラーゼ活性值

赤堀文昭 ${ }^{1)} \cdot$ 坂口和子 ${ }^{2)} \cdot$ 光崎龍子 $^{2)} \cdot$ 政岡俊夫 ${ }^{1)} \cdot$ 新井成之 ${ }^{1)}$

${ }^{1)}$ Department of Veterinary Pharmacology, School of Verterinary Medicine, Azabu University. 麻布大学獣医学 部薬理学

${ }^{2)}$ Department of Public Health Administration, College of Enviromental Health, Azabu University. 麻布大学環 境保健学部衛生行政学

Correspondence address : Fumiaki Akahori, Department of Veterinary Pharmacology, School of Verterinary Medicine, Azabu University, Sagamihara-shi, Kanagawa 229, Japan.

(Received February 6 1987, Accepted May 26 1987) 


\section{Introduction}

There have been numerous reports on a variety of serum cholinesterase (ChE) molecules in terms of purification $^{1)}$, a method of fractionation ${ }^{2)}$, genetic factors $^{3)}$, inter-transfer ${ }^{4)}$ and the relationship between $\mathrm{ChE}$ and disease ${ }^{5)}$. However, in our opinion $\mathrm{ChE}$ isoenzyme have not sufficiently been explored, as compared to lactate dehydrogenase (LDH). Of the previous investigations using laboratory animals, there are only the reports by Hess et al. ${ }^{6}$ and Bernson et al. ${ }^{7)}$ that describe the number of bands of $\mathrm{ChE}$ isoenzymes in such animals as cats and rats. We have previously reported sex- and age-related differences in $\mathrm{ChE}$ isoenzymes in Wistar rats $^{8)}$. In the present study we determined the $\mathrm{ChE}$ isoenzyme patterns for various laboratory animals using polyacrylamide gradient gel electrophoresis (PAGEp) to determine if there was a sex-related difference in these patterns and a possible relationship between these patterns and the $\mathrm{ChE}$ activities.

\section{Materials and Methods}

\section{Animals}

Rats (Shizuoka Laboratory Animal Center, Shizuoka), hamsters, guinea pigs, rabbits and quail (Nippon Institute for Biological Science, Ohme), dogs (Yamanashi Dog Breeding Center, Yamanashi) and monkeys, pigs and horses (Azabu University) were used, as listed in Table 1. For indoor breeding, the lighting schedule was 12 hours light: 12 hours dark, with the lights being turned on at 0600 .

2 . Sample collection and specimen preparation prior to assay

After the blood specimens were collected, the samples were centrifuged at 2,500 rpm for fifteen minutes. The separated serum samples were then processed with acetone and stored at $-20^{\circ} \mathrm{C}$ until they were assayed.

\section{Electrophoresis of the cholinesterase (ChE)}

The patterns of $\mathrm{ChE}$ isoenzymes were determined using PAG-Ep. The electrophoresis was performed at a constant current of $20 \mathrm{~mA}$ per gel at $10^{\circ} \pm 2^{\circ} \mathrm{C}$ for 80 minutes, using a $3.5 \sim 10.0 \%$ gradient separation gel and a $3 \%$ spacer gel, $1 \mathrm{~mm}$ thick. A $2 \mu \mathrm{l}$ aliquot of the serum specimen was applied to the gel for $\mathrm{ChE}$ isoenzyme analysis. The electrophoresis buffer was Tris-glycine, $\mathrm{pH} 8.4\left(22^{\circ} \mathrm{C}\right)$. This buffer was used undiluted for the cathodic compartment and diluted $1: 10$ for the anodic compartment. After the electrophoresis was complete, the gel was stained utilizing the method of Juul et al. $\left.{ }^{9}\right)$ Preincubation was performed for thirty minutes using $0.067 \mathrm{M}$ phosphate buffer $\left(\mathrm{pH} 6.1\left(22^{\circ} \mathrm{C}\right)\right)$, contain ing $0.01 \mathrm{M}$ glycine, $0.002 \mathrm{M} \mathrm{CuSO}_{4}$ and $0.03 \mathrm{M}$ $\mathrm{Na}_{2} \mathrm{SO}_{4}$ at $22^{\circ} \mathrm{C}$. Incubation was carried out in a solution containing $3.2 \mathrm{mM}$ acetylthiocholine (AcSCh) for ninety minutes. After the incubation was completed, the gel was transferred to a $3 \mathrm{M}$ ammonium sulfate solution and kept at $4^{\circ} \mathrm{C}$ for 24 hours. Copper (II)staining was performed by immersing the gel in $3 \mathrm{M}$ ammonium sulfate solution with dithiooxamide at $4^{\circ} \mathrm{C}$ for 24 hours. Finally the gel was placed in a $7 \%$ acetic acid solution for 24 hours before it was scanned at $620 \mathrm{~nm}$ in a transmission densitometer (Beckman DU-8). The individual $\mathrm{ChE}$ isoenzyme percentages were calculated from the integration counts of the individual peaks obtained from the scanning procedure.

\section{Enzyme assay}

The activity of the serum $\mathrm{ChE}$ was determined by Ellman's method ${ }^{10)}$.

Using Ellman's method, the total ChE activity was calculated from the increase in absorbance at $412 \mathrm{~nm}$ due to the reaction of thiocholine. The thiocholine was formed from the enzymatic hydrolysis of AcSCh with 5, 5-dithio-bis-2-nitrobenzoate ion, producing the yellowish 5-thio-2-nitrobenzoate ion. The reagent solution used was $3.0 \mathrm{ml}$ of $0.1 \mathrm{M}$ Tris- $\mathrm{HCl}$ buffer, $\mathrm{pH}$ 8.0, $20.0 \mu \mathrm{l}$ of $75 \mathrm{mM}$ AcSCh and $100 \mu 1$ of 5,5-dithio-bis-2-nitrobenzoic acid (DTNB) for assaying $50 \mu 1$ of serum sample.

The rate of non-enzymatic hydrolysis of AcSCh at $25^{\circ} \mathrm{C}$ was determined to be 0.0016 absorbance units per minute. 
Results and Discussion

\section{ChE isoenzyme}

Fig. 1 displays the $\mathrm{ChE}$ isoenzyme patterns from both Wistar and Spranque-Dawley(SD) rats obtained using the PAG-Fp procedure. Counting from the anodic side, six fractions (bands 1-6) were observed. Bands 5 and 6 were regarded as "main bands" and bands 1, 2 and 3 as "sub-bands". In addition, band 4 , a very faint band, was also detected.

Neither sex- nor strain-related variations was not found in the total number of the isoenzyme bands from the Wistar or SD rats. The authors thought it would be advantageous to take into consideration the variation in the molecular weights in the analysis of the serum $\mathrm{ChE}$ isoenzymes. For this reason, the PAG-Ep technique, with which a molecular sieving effect operates, was used instead of simple electrophoresis, which depends only upon the electric charges. In the work of Hess et al. ${ }^{6)}$ and Bernsohn et al. ${ }^{7)}$, they detected, using starch gel electrophoresis, the same total number of isoenzyme fractions in rats as we found, but the zymographic and densitometric patterns obtained in our study demonstrated a much clearer separation of the six bands (bands 1-6, counting from the anode) than what had been obtained using the starch gel electrophoretic technique. The $\mathrm{ChE}$ isoenzyme patterns and the proportions of each band detected for both Wistar and SD female rats are shown in Fig. 2. The proportion of each $\mathrm{ChE}$ band is expressed as percentage of the total $\mathrm{ChE}$ detected. Band 6 had the highest proportion (Wistar : $76 \%$, SD : $84 \%$ ), followed by band 5 (Wistar : $15 \%$, SD : $10 \%$ ). On the other hand, in the male Wistar and male SD rats, band 5 had the highest proportion (Wistar : $70 \%$, SD : $40 \%$ ), followed by band 6 (Wistar : $17 \%$, SD : $29 \%$ ).

Since the proportion (percentage) of bands 5 and 6 were reversed between the male and female of both strains, this indicates a sex-related difference. As the proportions of band 6 for male and female

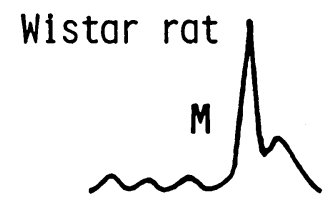

123456
S D rat

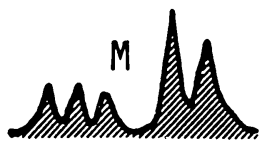

$123456(-)$

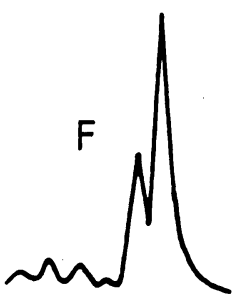

123456

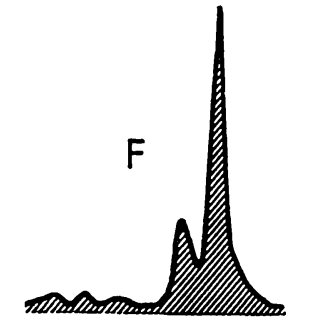

$123456(-)$
Fig. 1 ChE isoenzyme patterns for Wistar and SD rats.

$\mathrm{M}:$ male, $\mathrm{F}:$ female.

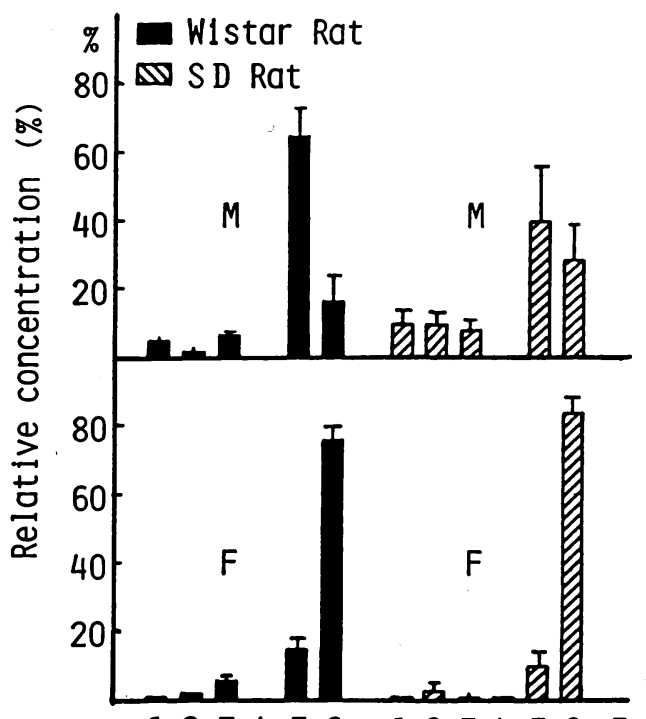

123456123456 Fr. No.

Fig. 2 Relative concentrations of $\mathrm{ChE}$ isoenzyme bands for Wister and SD rats.

$\mathrm{M}:$ male, $\mathrm{F}:$ female, Fr. No. : fraction number counting from the anodic side. 
$\mathrm{SD}$ rats were significantly much higher than were found in the Wistar rat strain, a strain-related variation was indicated. Thus, the proportion (relative concentration) of fractions of the serum $\mathrm{ChE}$ isoenzymes in the rat strains was proven to vary by sex and also between the different strains of rats (Wistar and SD).

Fig. 3 shows the patterns of $\mathrm{ChE}$ isoenzymes from different animal species obtained using the PAG-Ep procedure. For these different laboratory animals, Fig. 4 illustrates the proportions of each $\mathrm{ChE}$ band. The total numbers of fractions of the ChE isoenzyme found in the horses, pigs, dogs, monkeys, rabbits, guinea pigs, hamsters and quail were 4, 3, 3 $-5,3,4,3,4$, and 3 bands, respectively. The speciesrelated variation of these animals was demonstrated in the total number of $\mathrm{ChE}$ fractions that we detected. Although a sex-related variation was found in the rats, similar differences were not observed in these animals.

\section{ChE activity}

The activities of serum $\mathrm{ChE}$ are compared between Wistar and SD rat strains in Fig. 5. In this comparison, the female rats had higher $\mathrm{ChE}$ activity than the males. Therefore, sex-related differences were found in the activities of ChE from both rat strains, as well as in the proportions of the individual $\mathrm{ChE}$ bands. Moreover, this comparison of the $\mathrm{ChE}$ activity demonstrated that the female SD rats had a higher activity than the female Wistar rats.

Substrate specificity was investigated by Matsumoto et al. ${ }^{11)}$ concerning age- and sex-related differences in the serum ChE activity of rats. Matsumoto et al. ${ }^{11)}$ also reported that AcSCh was the preferred substrate for rats. Our results have confirmed this earlier observation.

We found a possible relationship between the serum $\mathrm{ChE}$ activity and the "main bands" of the ChE isoenzymes, as the ChE activity observed in the female rats was higher than that found in male rats for all age groups we examined. Thus, it appears that there is a relationship between the serum $\mathrm{ChE}$ activity and the proportions of the $\mathrm{ChE}$ isoenzyme bands detected in the rats.

In Fig. 6 the serum $\mathrm{ChE}$ activities of both male and female animals (horses, pigs, dogs, monkeys, rabbits, guinea pigs, hamsters and guail) are illustrated for comparison. Sex-related variations in the ChE activity for these animals were not observed.

Table 1.

\begin{tabular}{llrr}
\hline Animal & Strain/Species & \multicolumn{2}{c}{ Number of Animals } \\
\hline \multirow{2}{*}{ Rat } & Wistar $(12 \mathrm{w})$ & $12(\mathrm{M})$, & $12(\mathrm{~F})$ \\
& SD $(12 \mathrm{w})$ & $16(\mathrm{M})$, & $10(\mathrm{~F})$ \\
Hamster & Djungarian & $18(\mathrm{M})$, & $6(\mathrm{~F})$ \\
Guinea pig & Hartley & $28(\mathrm{M})$, & $6(\mathrm{~F})$ \\
Rabbit & JW-NIBS & $23(\mathrm{M})$, & $28(\mathrm{~F})$ \\
Monkey & Macaca fuscata & $5(\mathrm{M})$, & $8(\mathrm{~F})$ \\
Dog & Beagle & $23(\mathrm{M})$, & $28(\mathrm{~F})$ \\
Pig & Yorkshire & $15(\mathrm{M})$, & $26(\mathrm{~F})$ \\
Horse & Thoroughbred & $7(\mathrm{M})$, & $6(\mathrm{~F})$ \\
Quail & JaPanese & $5(\mathrm{M})$, & $35(\mathrm{~F})$ \\
\hline
\end{tabular}

(M)-male, (F)-Female 

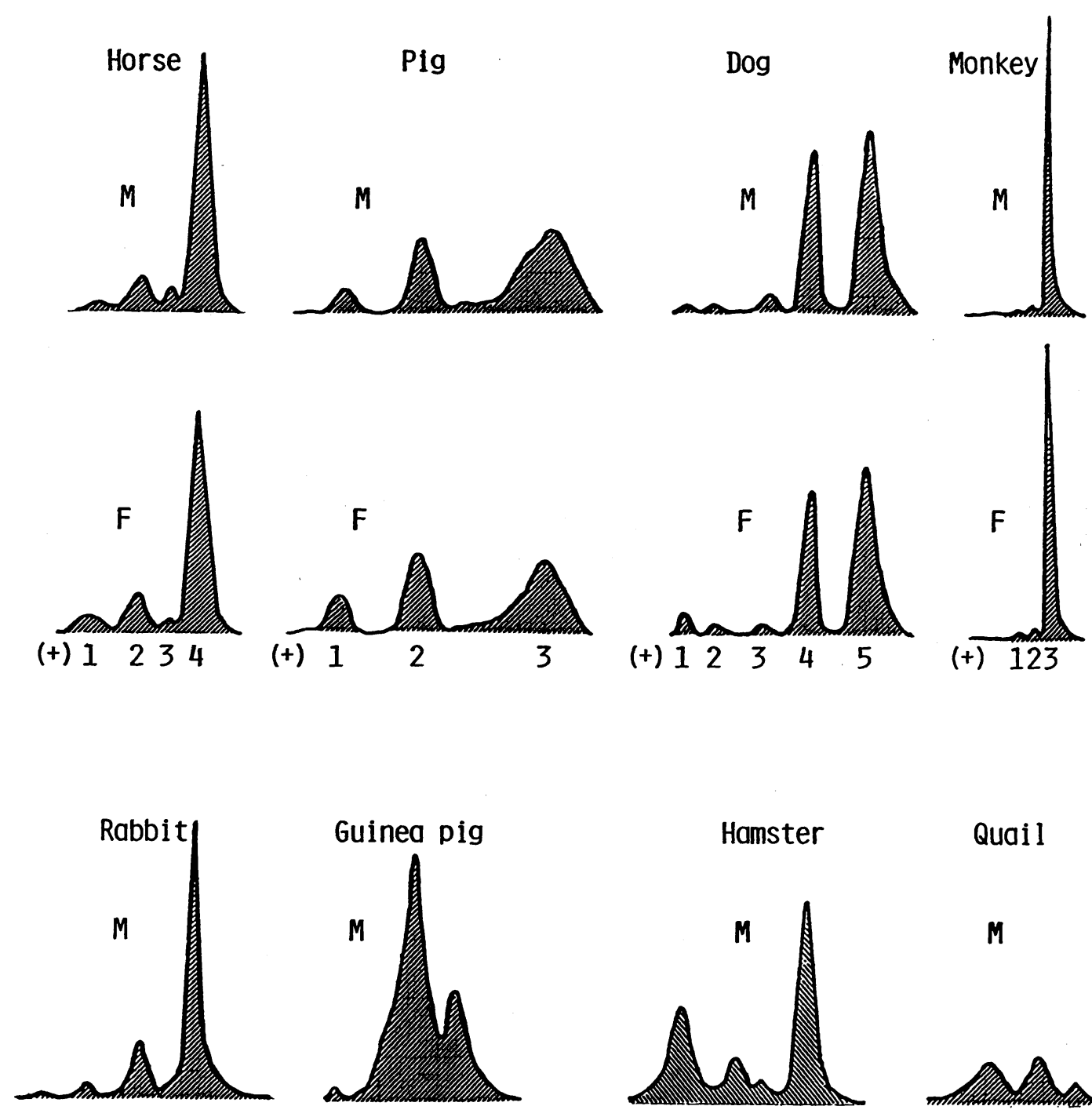

Hamster

Quail
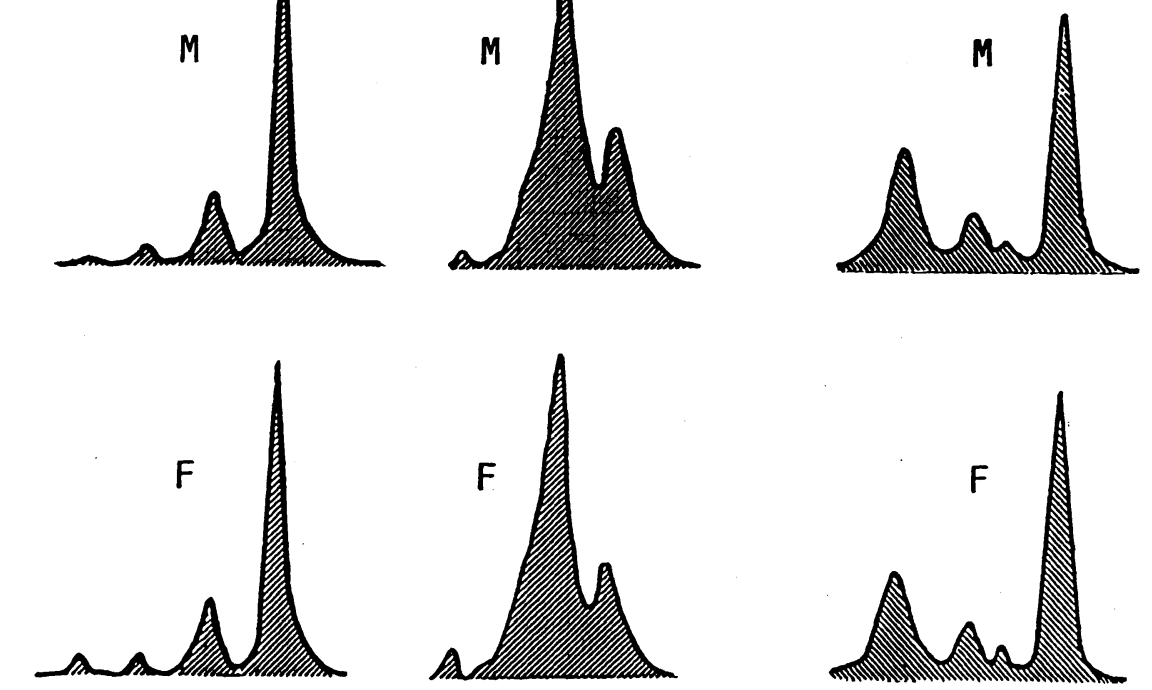

(+) 1234

(+) 123

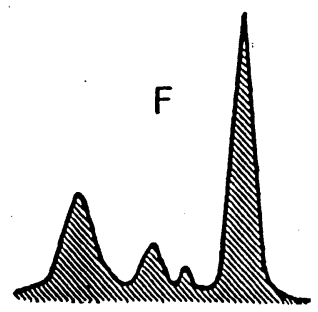

(t) 1234
M

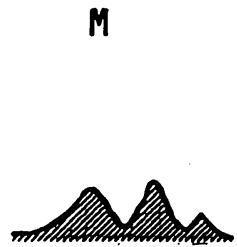

F

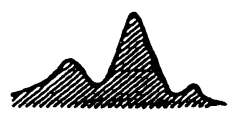

(t) 123

Fig. $3 \mathrm{ChE}$ isoenzyme patterns for various laboratory animal species. $\mathrm{M}$ : male, $\mathrm{F}$ : female. 
(238) The Physico-Chemical Biology

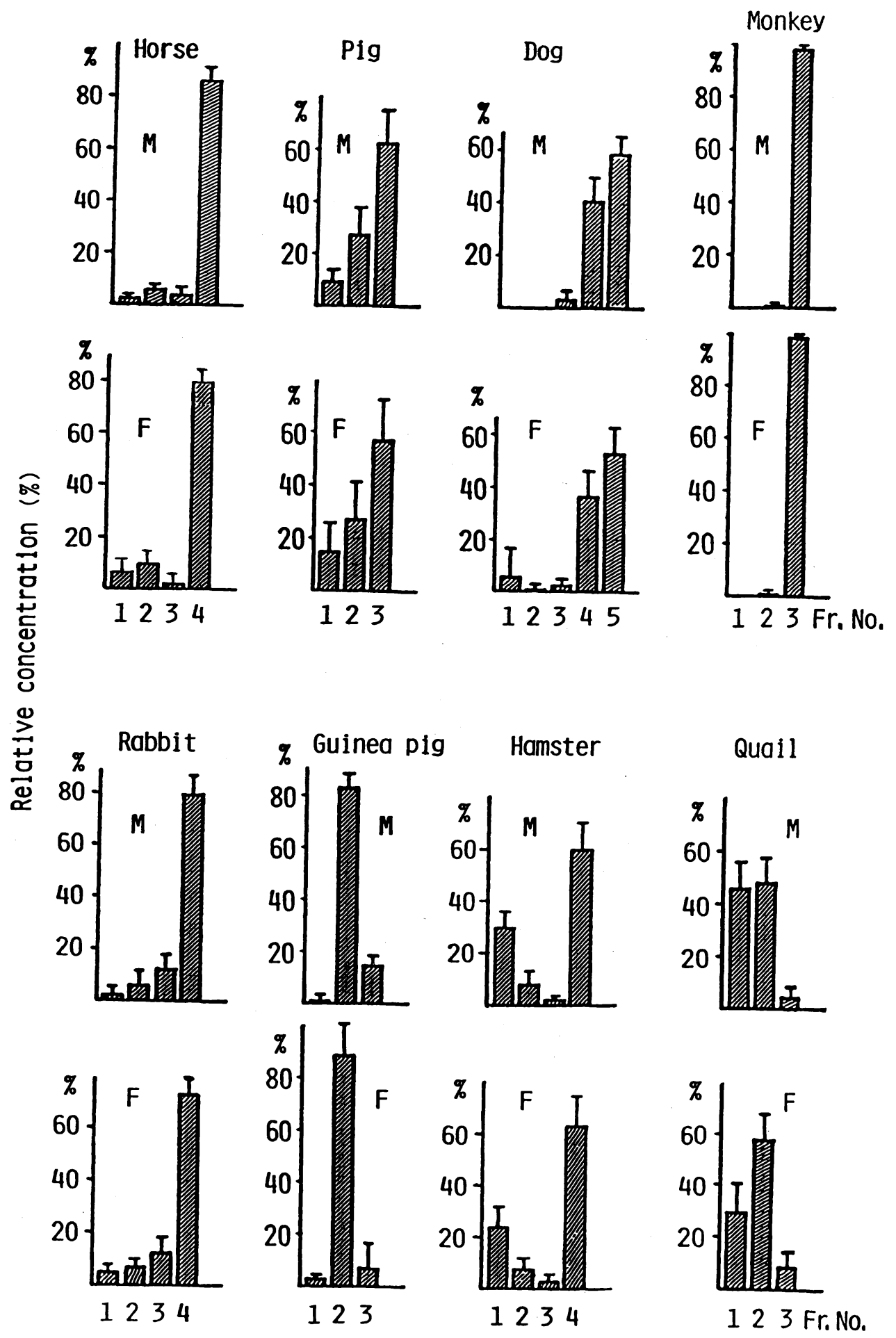

Fig. 4 Relative concentration of $\mathrm{ChE}$ isoenzyme bands of various laboratory animal species. $\mathrm{M}:$ male, F : female, Fr. No. : fraction number counting from the anodic side. 


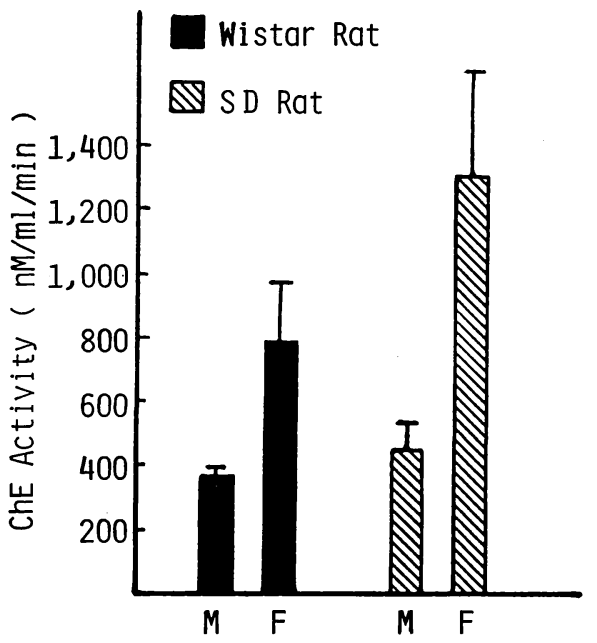

It is important, for future research, to be specific as to the species, strain, sex and age of the laboratory animals used for serum $\mathrm{ChE}$ determinations and to decide what would be the most appropriate substrate for the animal used. From the data collected from our present study, various laboratory animals were determined to have species-related variations in the total number of their $\mathrm{ChE}$ fractions. These results suggest that there were species-related differences in the mode of polymerization of the serum $\mathrm{ChE}$ subunits that constitute the ChE isoenzymes.

Fig. 5 Serum ChE activity of Wistar and SD rats. $\mathrm{M}$ : male, $\mathrm{F}$ : female.

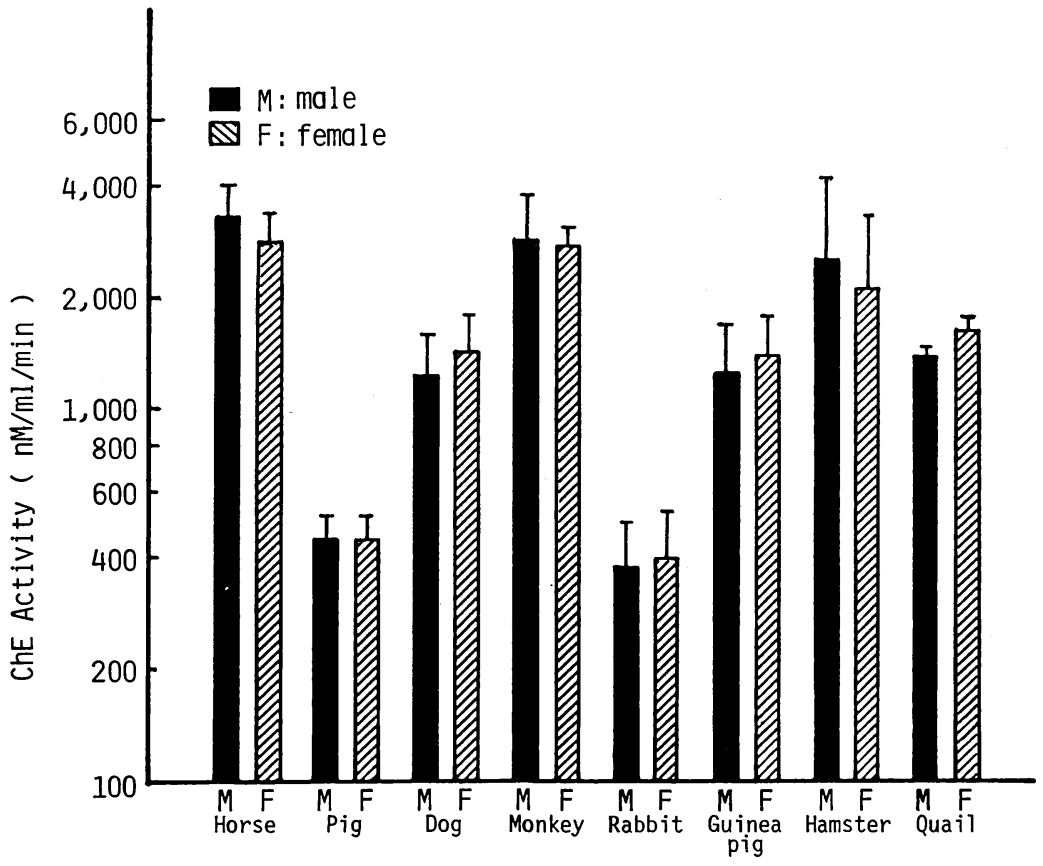

Fig. 6 Serum ChE activity of various laboratory animal species. $\mathrm{M}$ : male, $\mathrm{F}$ : female. 


\section{要旨}

各種実験動物における Cholinesterase (ChE) 活性值 と ChE isoenzyme pattern との関連性を追究するた め, Ellman'法により ChE 活性を, また, PAG-Ep 法 により ChE isoenzyme pattern を検討した。1) Wistar 系および SD系ラットの ChE isoenzyme pattern はいずれも 6 分画からなり，分画数のうえには性差な らびに年令差はみられなかった。しかし，ChE isoenzyme band の相対比においては, 両系のラットでいず れも性差が認められ，また，血清 $\mathrm{ChE}$ 活性值において も性差が同様に観察された，2)一方, 各動物種の ChE isoenzyme band 数は，ジャンガリアンハムスター, JW-NIBS ウサギおよU゙サラブレッド系ウマで各 4 本, ハートレイ系モルモット, 日本ザル, ヨークシャー系 ブタおよびWE系日本ウズラで各 3 本，また，ビーグ ル犬では 3 ～ 5 本であった。 3）今回供試した実験動 物における ChE isoenzyme bandの相対比ならびに $\mathrm{ChE}$ 活性值にはラットを除いて性差が認められなか った. 4) 各動物とも ChE isoenzyme の特定の band が ChE 活性值と関係のあることが推察される。

\section{References}

1) Harris, H. et al. : Biochim. Biophys. Acta, $73: 649,1963$.

2) Harris, H. et al. : Nature, $196: 1296,1962$.

3 ) Harris, H. et al. : Nature, 200: 1185, 1963.

4) Lamotta, R. V. et al. : Can. J. Phys. Pharm., $43: 313,1965$.

5 ) Shibata, H. et al. : Jpn. J. Gastroenterol., $76: 196,1979$.

6 ) Hess, A. R. et al. : Clin. Chem. Acta, $8: 656$, 1963.

7 ) Bernsohn, J. et al. : Exp. Biop. Med., 108 : 71, 1961.

8 ) Sakaguchi, K. et al. : Physico-Chem. Biol., 31: 1, 1987.

9 ) Juul, P. and Deopold, I. H. : Am. J. Ophth., 65: 527, 1968.

10) Ellman, G. L. et al. : Biochem. Pharmacol., $7: 88,1961$.

11) Matsumoto, K. et al. : Igaku no ayumi, $109: 672,1979$. 